\title{
Implementation of geriatric care models in Europe (imAGE.eu): a cross-sectional survey in 8 countries
}

\author{
Mieke Deschodt ${ }^{1,2}$, Benoit Boland ${ }^{3}$, Cecilia M. Lund $^{4}$, Kai Saks ${ }^{5}$, Venetia-Sofia Velonaki ${ }^{6}$, \\ Olafur Samuelsson 7 , Sean Kennelly ${ }^{8}$, Mark Anthony Vassallo ${ }^{9}$, Gregor Veninšek ${ }^{10}$, \\ Johan Flamaing ${ }^{1,11}$
}

${ }^{1}$ Gerontology and Geriatrics, Department of Chronic Diseases, Metabolism and Ageing, KU Leuven University of Leuven, Herestraat 49, 3000 Leuven, Belgium.

${ }^{2}$ Nursing Science, Department of Public Health, University of Basel, Bernoullistrasse 28, 4056 Basel, Switzerland. ORCID: 0000-0003-1560-2277

${ }^{3}$ Geriatric Medicine, Cliniques Universitaires Saint-Luc, Brussels \& Research Institute of Health and Society, UCLouvain, Belgium

${ }^{4}$ Danish Geriatric Society \& Copenhagen University Hospital, Herlev and Gentofte, Herlev Ringvej 75, 2730 Herlev, Denmark

${ }^{5}$ Estonian Association of Gerontology and Geriatrics (EGGA) \& University of Tartu, Puusepa 8 L6027, Tartu, Estonia 51014

${ }^{6}$ Hellenic Association of Gerontology and Geriatrics (HAGG), Kaniggos 23, 106 77, Athens, Greece

${ }^{7}$ The Icelandic Geriatrics Society \& and Landspitali University Hospital, Hringbraut 101, 101 Reykjavík, Iceland

${ }^{8}$ Department of Age-related healthcare, Tallaght University hospital, Dublin; Irish Society of Physicians in Geriatric Medicine. ORCID: 0000-0002-3721-0197

${ }^{9}$ Geriatric Medicine Society of Malta; Rehabilitation Hospital Karin Grech, Telghet G'Mangia, Pietà, Malta

${ }^{10}$ Slovene Geriatric Medicine Society \& Geriatric Medicine Unit, Division of Internal Medicine, University Medical Centre Ljubljana, Vodnikova 62, 1000 Ljubljana, Slovenia

${ }^{11}$ Belgian Society for Gerontology and Geriatrics \& University Hospitals Leuven, Department of Geriatric Medicine, Herestraat 49, 3000 Leuven, Belgium

Corresponding author: Mieke Deschodt, e-mail: mieke.deschodt@kuleuven.be ; phone +32 163776 92. 


\section{Acknowledgements}

The authors gratefully acknowledge the support of Sofie Nullens and Ruth leven in the development and validation of the survey questionnaire, and Prof P. Sourtzi and Dr M. Velonaki for assisting in the data collection process in Greece. We also thank the national geriatric societies of Austria, Germany, United Kingdom, Luxembourg and Serbia for all their efforts in distributing the survey questionnaire in their countries. The study was funded by internal funds of the Gerontology and Geriatrics research unit of the University of Leuven in Belgium.

\section{ABSTRACT}

Purpose: Despite the beneficial impact of comprehensive geriatric assessment (CGA) for older patients in the hospital, it is not clear to what extent these models have been implemented in European hospitals. This study aims to map the implementation status of CGA-based models of care in general hospitals in Europe.

Methods: A cross-sectional survey study was conducted in autumn 2017 to map the implementation status of CGA-based care models in general hospitals $(n=178)$ in Belgium, Denmark, Estonia, Greece, Iceland, Ireland, Malta, and Slovenia.

Results: Acute geriatric units are implemented in all of the Belgian and the majority of Danish hospitals, but are scarce in Malta, Estonia, Slovenia and Greece. Geriatric rehabilitation units are most common in Ireland (63.6\%) and Iceland (75\%). Inhospital multidisciplinary geriatric consultation teams are widely implemented in Belgium (100\%), Ireland (72.7\%) and Denmark (59.1\%), but are rare in Malta, Iceland, Estonia and Greece. Transitional care programs to ensure continuity of care after discharge are present in $60.1 \%$ of all hospitals. The intention to implement any of these care models in the next five years ranges from $10.3 \%$ to $25.4 \%$ and is the highest for co-management $(36.5 \%)$, systematic screening of ED patients (36.2\%) and transitional care programs (29.6\%).

Conclusions: A great variety in the implementation of CGA-based care models was observed among the surveyed EU countries with the uptake being the highest in Belgium, Denmark and Ireland. A supportive legislative framework and a residency training in geriatrics favour the implementation of the geriatric care models.

Key words: models of care; comprehensive geriatric assessment; implementation; survey 


\section{INTRODUCTION}

Comprehensive geriatric assessment (CGA) has been defined as "a multidimensional interdisciplinary diagnostic process focused on determining a frail older person's medical, psychological and functional capability in order to develop a coordinated and integrated plan for treatment and long term follow up" [1]. This process ensures that geriatric problems are quickly detected and treated appropriately in frail older people at higher risk for developing geriatric syndromes when admitted to the hospital $[2,3]$. CGA is considered to be one of the cornerstones of modern geriatric care.

Different CGA-based models of care for geriatric inpatients, such as acute geriatric units, consultation teams, co-management teams and specific models for the emergency department, have been described in the literature. Acute geriatric units are defined medical units that have been designed specifically to prevent functional decline and related complications in frail older adults admitted to the hospital for an acute event [4-6]. Several meta-analyses have shown that admission on an acute geriatric unit prevents in-hospital functional decline, decreases mortality and institutionalization rates and results in shorter length of stays, a lower incidence of delirium, fewer falls, more discharges to home and lower costs $[7,8,6]$. Inpatient geriatric consultation teams (IGCTs) are mobile multidisciplinary teams that conduct CGA, formulate care recommendations and develop an evidence-based care plan for frail older patients admitted to non-geriatric wards [9-11]. Although a meta-analysis could only show a beneficial effect of IGCT interventions on mortality rate up to 8 months post-discharge, individual studies also demonstrated improved functional outcomes, decreased incidence of delirium, and decreased readmission rates in patients seen by the IGCT.[14]. Geriatric co-management models are characterized by a shared responsibility and decision making between at least one primary treating physician and a geriatrician or interdisciplinary geriatric team in the prevention and management of geriatric-oriented problems [12, 13]. A recent meta-analysis including 12 prospective quasi-experimental studies showed a beneficial effect on complications, length of stay and in-hospital mortality, but included studies were at medium to high risk for bias [14]. Finally, several geriatric care models were designed to address the needs of older people in the emergency department (ED), such as the use of discrete geriatric boxes that are especially equipped for older patients and have a multidisciplinary team of specialists available for quicker decisionmaking regarding hospital admission or discharge [15]. A recent meta-analysis suggested that discrete geriatric boxes at the ED have infrastructural benefits and seem to nourish consistent geriatric-oriented practice and the development of geriatric expertise [15]. Some models have demonstrated reductions in hospital length of stay or readmission rates. Offering multidisciplinary CGA at ED observation units has also been found feasible and resulting in targeted interventions [16]. With regard to ED community transition strategies, a meta-analysis could not indicate a benefit for 
unplanned hospital or ED readmissions up to 30 days or mortality up to 18 months, but found mixed results for functional decline and nursing home admissions [17].

Despite the beneficial impact of CGA-based models of care on patient, organizational and system level $[18,19,7,6,20,21,8]$ and CGA being recommended by the European Geriatric Medicine Society as being the gold standard for geriatric care, it is not clear to what extent these models have actually been implemented in European hospitals and whether there is a gap between the current evidence regarding CGA-based care models and their implementation in daily clinical practice. This study therefore aims to map the implementation status of CGA-based models of care in Europe.

\section{METHODOLOGY}

\section{Design and sample}

A cross-sectional survey study was conducted in Belgium, Denmark, Estonia, Greece, Iceland, Ireland, Lithuania, Malta and Slovenia. Although all European countries were eligible to participate, we only distributed the survey in countries were the national geriatric society or another representing body was willing to serve as a national coordinator for that country. In these eight countries, all public and private general hospitals were invited to participate in the survey, whereas psychiatric or specialized hospitals were excluded from the study. One survey per hospital was to be submitted.

\section{Development of questionnaire}

The survey questionnaire was drafted based on a comprehensive literature search in Medline, Cochrane Library and Trip to identify the different CGA-based models of care for older hospitalized patients and based on the available expertise in the research team. The research team discussed the developed questions internally to improve their clarity and determine the right order and wording. Then, a panel of 24 international experts with clinical and academic expertise in geriatric care models was set up for validation of the questionnaire. The 46 questions that were sent out for validation to this expert panel were subcategorized in different themes, i.e. information about the hospital, presence and organizational aspects of geriatric care models for older inpatients and models in emergency departments and geriatric day clinics. It concerned yes/no-questions, open questions and multiple-choice questions. Experts were given two weeks to complete their validation. An e-mail reminder was sent to those who did not reply before this deadline.

The content validity of the survey questionnaire was evaluated based on the method of Lynn [22]. Every item of the questionnaire was rated on clarity and relevance by the expert panel. Clarity was rated by simply giving a yes-or-no answer. Relevance of each item had to be evaluated on a 4-point Likert scale ( $1=$ not relevant, 2 = somewhat relevant, $3=$ quite relevant, $4=$ highly relevant $)$ and 
experts were asked if items were missing. Once scoring was completed by the experts, the itemcontent validity index (I-CVI) and the scale-content validity index (S-CVI) were calculated. The I-CVI was computed as the number of experts giving a rating of either 3 or 4 , divided by the number of experts. Questions with an I-CVI below 0.73 were revised or removed from the questionnaire. We also calculated a modified kappa index to adjust for chance agreement [23]. Items with an excellent modified kappa index $(0.74-1)$ were accepted. Items with a good $(0.6-0.73)$ or fair $(0.4-0.59)$ kappa scored were revised, while items scoring below the threshold of 0.40 were rejected. The S-CVI consisted of two different scores. We calculated the average score of all the I-CVI's that were obtained (S-CVI/Average) and the level of universal agreement (UA) between the experts. This S$\mathrm{CVI} / \mathrm{UA}$ was calculated as the number of questions that had a rating of 3 or 4 by all of the experts (meaning that the I-CVI was 1 ) divided by the total number of questions in the questionnaire. The recommended cut-off score for the S-CVI is 0.80 [23].

The final version of the English survey was programmed in LimeSurvey, an online survey tool provided by the University of Leuven, Belgium. Thereafter the questionnaire was pilot-tested to evaluate the usability and estimate time investment by two geriatricians of the University Hospitals Leuven who were not involved in the development of the questionnaire. After pilot-testing, the questionnaire was translated into Danish, Dutch, French, German, Greek, Lithuanian, Serbian, Slovene and Estonian to increase the likelihood of high response rates in the selected countries. A forward translation was conducted by a native speaker who is also proficient in the English language.

\section{Distribution of the questionnaire}

Potential national coordinators were identified by distributing flyers at the 2016 EUGMS Congress in Lisbon and by contacting all national societies for gerontology and geriatrics in EU countries and personal contacts of members of the research team. Once identified, national coordinators and their respective national societies were informed about the research aims, procedures and timeline of the study. The national coordinators' tasks included 1) translating the questionnaire into their native language, 2) distributing the invitation for survey participation and the link to the online questionnaire to all general hospitals in their country, 3) sending regular reminders to all hospitals in their country and 4) if available, publishing the link to the online questionnaire on their website. The online survey was open from September through December 2017. National coordinators chose when and how they distributed the link to the online survey, and when and how many reminders were sent.

\section{Respondents}


The survey questionnaire was sent out to the internal medicine physicians, geriatricians or geriatric expert nurses of the hospital as they were considered to have the appropriate knowledge to fill out the questionnaire. Potential respondents received written information about the purpose of the study and were informed that participation in the study was voluntary. The name and e-mail address of the respondents was requested so we could contact them if needed.

\section{Data analysis and ethics}

Descriptive analyses were performed on the total sample and per country using IBM SPSS Statistics version 25. Nominal and categorical variables are reported as numbers and percentages. Continuous data are reported as means and standard deviations. The data of Austria $(n=6$, response rate $4 \%$ ), Germany $(n=2$, response rate $2 \%$ ), Luxembourg $(n=1$, response rate $25 \%)$, Serbia $(n=7$, response rate $18 \%$ ) and United Kingdom ( $n=9$, response rate $5 \%$ ) are not presented in this paper as the response rates were considered too low to be meaningful. The imAGE.eu study was approved by the Ethics Committee of the University of Leuven, Belgium (file number: mp13726).

\section{RESULTS}

\section{Development and validation of the questionnaire}

Eleven experts (response rate 45.8\%) evaluated the draft questionnaire. An excellent modified kappa score (>0.74) was obtained for 31 of the 46 questions (67\%). Ten questions had a good and five questions a fair modified Kappa index and were revised. The S-CVI/UA was 0.17 and the S-CVI/Ave was 0.81 . The results per question are presented in Table 1. Based on the ratings and recommendations of the experts, different adjustments were made to the questionnaire. Five out of the 15 questions that were up for revision were excluded (6c, 6d, 7c, 7d and 11b). One extra question was formulated to improve the clarity (question 11 in final questionnaire), resulting in a final questionnaire of 42 questions (S-CVI/Ave: 0.86 and S-CVI/UA: 0.21). The seven questions regarding demographic characteristics of the respondents were not validated by the expert panel.

\section{General characteristics of respondents and hospitals}

A total of 178 questionnaires were filled out resulting in an overall response rate of 50\%, ranging from $27 \%(n=47)$ in Greece to $100 \%(n=22)$ in Denmark. Mean age of the respondents was 48.9 $( \pm$ SD 9.8) years with the majority being a geriatrician $(n=84 ; 47.2 \%)$ or internal medicine physician ( $n$ $=40 ; 22.5 \%$ ). Over $74 \%$ of the hospitals were general hospitals, $20 \%$ were university hospitals and $6 \%$ were mixed (general hospital with university beds). The median number of beds per hospital ranged from 70 in Iceland to 420 in Belgium. Geriatricians are employed in the majority of the participating 
hospitals in Ireland $(n=11 ; 100 \%)$, Belgium ( $n=68 ; 98.6 \%)$ and Denmark $(n=19 ; 86.4 \%)$. Other characteristics are described in Table 1.

\section{Implementation of CGA-based models of care}

Acute geriatric units are implemented in all of the Belgian and the majority $(n=16 ; 72.7 \%)$ of Danish hospitals, while they are scarce or non-existing in Malta, Estonia, Slovenia and Greece (see Table 2). The median length of stay in these units is 13 days with the shortest mean durations reported in Denmark and Slovenia ( 7 days) and the longest in Iceland (30 days). The median number of beds at the geriatric units ranges from 16 in Slovenia to 60 in Belgium.

Geriatric rehabilitation units are common in Irish $(n=7 ; 63.6 \%)$ and Icelandic $(n=3 ; 75 \%)$ hospitals, and implemented to some extent in Belgium ( $n=21 ; 30.4 \%$ ) and Denmark ( $n=5 ; 22.7 \%)$. The median number of bed ranges from 5 in Estonia to 24 in Belgium.

Multidisciplinary geriatric consultation teams are implemented on a large scale in Belgium (100\%), Ireland (72.7\%) and Denmark (59.1\%), but are rare in Malta, Iceland, Estonia and Greece (range 4.325.0\%). There are no geriatric consultation teams in Slovenia. Geriatricians (97.9\%) and nurses (87.6\%) are represented in almost all consultation teams. In Denmark geriatric nurse specialists (61.5\%) and physiotherapists (61.5\%) are the main health care disciplines represented. Interventions mainly take place on the medical and surgical wards in the hospital, although about half of the teams in Ireland and Denmark also intervene in the emergency department. Outreach to nursing homes is only done by teams in Estonia (66.7\%), Denmark (46.2\%) and Ireland (25.0\%).

Geriatric co-management teams or wards are present in one out of three of the hospitals included in this survey. They are most often implemented in Malta (100\%), Denmark (63.6\%) and Belgium (40.6\%), while Iceland and Slovenia do not provide geriatric co-management. The geriatricians and nurses who are represented in the majority of the teams are most often accompanied by occupational and physiotherapists.

The majority of the hospitals (97.2\%) have an ED. In Iceland (75.0\%), Ireland (80.0\%), Belgium (70.6\%) and Denmark (77.3\%) geriatricians are available for interventions at the $E D$, but mostly upon request and not systematically. Overall, geriatric boxes are rare in hospitals with an ED ( $n=9 ; 5.2 \%)$. Systematic screening of older patients for having a geriatric profile and being at risk for adverse outcomes is implemented in about one third (35.8\%) of the hospitals, but mainly in Belgium (66.2\%) and Ireland (60.0\%).

Three quarters of the hospitals in Belgium and about one quarter of the hospitals in Ireland, Iceland and Denmark have a geriatric day clinic. Memory clinics and falls prevention clinics are implemented in $56.2 \%$ and $48.3 \%$ of the hospitals respectively, with the highest proportions observed in Belgium (89.9\% and $79.7 \%)$, Ireland (72.7\% and 63.6\%) and Denmark (54.5\% and $72.7 \%)$. 
Transitional care programs, defined as a structural collaboration with external partners, such as nursing homes, general practitioners, home care organizations and case managers, to ensure coordination and continuity of care after hospital discharge, were reported to be present in $59.8 \%$ of the hospitals. They were less common in Greece and Slovenia (34\% and 33\% respectively).

\section{Intention to implement models of care}

The intention to implement any of the discussed models of care in the participating hospitals ranges from $0.7 \%$ to $12.1 \%$ in the next year and from $10.3 \%$ to $25.4 \%$ in the next five years (See Table 3 ). The overall intention for implementation is the highest for geriatric co-management models (36.5\%), systematic screening of older patients at the ED (36.2\%) and transitional care programs (29.6\%).

Both in Ireland and Slovenia at least a quarter of the hospitals aim to implement acute units, rehabilitation units, consultation teams, co-management teams, ED boxes, systematic ED screening and transitional care programs for older patients in the next five years. Hospitals in Estonia are not planning to implement any of the CGA based models of care in the next five years, except for one hospital intending to implement an acute geriatric units and geriatric rehabilitation unit in the next five years.

\section{DISCUSSION}

The imAGE.eu survey mapped the 2017 implementation status of CGA-based models of care in 178 hospitals in eight European countries and reports the intention for implementation of these models in the upcoming years. Overall, CGA-based models of care are most widely implemented in Belgium, Denmark and Ireland, while the uptake has been lower in the other surveyed countries.

In a 2017 Cochrane meta-analysis it was confirmed that acute geriatric units are still the preferred model of care for hospitalized older patients with a geriatric risk profile. Despite the mounting evidence of their positive effect $[7,6,8]$, Malone et al. estimated that in 2014 merely between 100 and $200(1.8-3.6 \%)$ of the over 5500 acute care hospitals in the United States had Acute Care for the Elderly units [24]. Although the overall results of this imAGE.eu survey demonstrated better results for the surveyed countries, the scale of the implementation varies largely between Belgium and Denmark on the one hand, and the remaining countries on the other hand.

A first important element that seems to influence the implementation status of models of care for older adults is the presence of a national framework or legislation either mandating or encouraging the implementation of certain care models. The large uptake of CGA-based care models in all 
hospitals in Belgium is mainly due to the National Care Program for geriatric patients that has been in place since 2007 [25]. This Care Program aims to pursue the highest possible level of functional independence and quality of life for all hospitalized older patients, and structures hospital care for older patients around five models of care, i.e. acute geriatric units; outpatient consultations by a geriatrician; multidisciplinary geriatric day clinics; IGCTs and an external geriatric liaison function [25]. Moreover, since January 2014, each acute hospital with an accredited geriatric department receives funding for 2 to 6 fulltime equivalents (FTE) to staff the IGCT (geriatrician not included). In Denmark as well, a relatively small country with approximately 100 specialists in geriatric medicine, a national care program regarding frail older patients was implemented in 2016. This programs aims to 1) reduce the number of patients not being discharged from hospitals despite being ready for discharge, 2) reduce the number of patients readmitted to the hospital and 3) create better transitions between the hospital, general practice and the municipalities [26]. Also in Ireland, the development of a national clinical care program in Older persons issued by the Health Service Executive, the publication of a clear policy document defining what specialist geriatric services are, and a pathway to implementation have led to overall enhanced older persons services [27]. In Slovenia, a strategic governmental document has been published, [28] which has not yet resulted in a large uptake of geriatric care models, but the potential impact seems promising with the establishment of the first acute geriatric unit in Ljubljana in 2013. Although not surveyed in this study, previous research demonstrated that CGA-based models of care are also widely implemented in France under the impulse of Geriatric Care Network decreed in 2002 and revised in 2007 by the Ministry of Health [29]. A Network consist out of a geriatric short-stay unit, an IGCT attached to the former, a geriatric outpatient consultation unit, a geriatric day clinic and a geriatric rehabilitation unit [30]. These examples clearly demonstrate that having a national policy regarding older patients not only supports the implementation of the models mentioned in the legislation, but also stimulates the implementation of other models of care that are beneficial for older patients. A similar evolution was seen in the Netherlands after the introduction of a national Senior Friendly Hospital label: geriatric consultation teams were increasingly implemented in Dutch hospitals, because the presence of a geriatric consultation team was one of the fourteen quality indicators and a requirement for a hospital to receive the Senior Friendly Hospital Quality Label [31].

Having sufficient capacity in the system, in terms of the number of geriatric specialists and residents, is a second crucial element supporting the implementation as the medical geriatric expert is a core professional in all CGA-based models of care. The low uptake of CGA-based models of care in Greece for example can be attributed to the lack of health professionals specialized in geriatrics. The medical specialty or subspecialty of geriatric medicine is not yet recognized [32], although the Hellenic 
Association of Gerontology and Geriatrics has been pushing this idea forward since 1977. This means that even geriatricians specialized abroad cannot work as geriatricians in Greek hospitals, unless they have another recognized medical specialty. Consequently, models of care are only present when certain individuals or groups with relevant knowledge initiate the implementation of any of the geriatric services discussed. Also in Estonia, geriatric medicine is a novel discipline. Although fifteen physicians have been certified by the Estonian Society of Geriatrics as having geriatric competence after taking several courses and training, it took until 2011 for the first resident to start a training in internal medicine with geriatric subspecialty. Hence, lack of trained geriatricians, but also the lack of job opportunities for geriatricians are currently hindering the implementation of CGA-based models of care in Estonia. Also in Slovenia the lack of a concept of who, how and where geriatric services should be delivered is hindering the development of geriatric medicine as specialty and vice versa. In contrast, young doctors' interest in geriatric medicine is rapidly growing in Denmark in line with a duplication of number of available educational positions in geriatric medicine from 2008 to 2018 [33]. The abovementioned national trends clearly demonstrate the link between on the one hand geriatric training and on the other hand having sufficient geriatric experts in the system - not only medicine, but also nursing and other allied health care professionals that are involved in the multidisciplinary care of frail older adults. As the presence of an educational system providing geriatric training is a requirement to be able to increase capacity, it should be a priority for decisionmakers. It also indicates that it might take another five to ten years before countries currently lacking geriatric training can further invest in the necessary implementation of CGA-based models of care.

Both in Iceland and Malta, with populations around 400.000 people, care for hospitalized older people is organized in a particular way. Iceland only has one large hospital in the capital and five smaller ones in the more rural areas of the country. An acute geriatric unit is only present in the large university hospital in Reykjavik, while geriatricians are available upon request in view of specific needs in the rural hospitals. In Malta, geriatrics services have always been taken up in a specialized geriatric hospital. Although there were plans to include an acute geriatric unit in the new university hospital, the number of beds in the geriatric hospital was increased from the initial 60 in 1991 to 250 in 2007 instead. Hence, inhospital geriatric care in the university hospital remains on a consultative basis provided by a geriatrician. Proactive orthogeriatric care has been implemented now for 10 years for patients aged 70 years and over with a fracture neck of femur. The service has expanded remarkably by going from the initial 6-bedded orthogeriatric unit in 2008 to covering all eligible patients admitted to the two trauma wards at the general hospital. Other geriatric services, such as outreach activities from geriatricians to community and residential care, are also implemented to a large extent. 


\section{Methodological considerations}

Surveys as the one reported here have limitations. First, the response rate of $45.8 \%$ for validation of the questionnaire was moderate. However, the participation of 11 experts was well above the minimum number of five experts as recommended by Lynn [27]. Also, although only one round of validation was organized, we observed an increase of S-CVI/Ave and UA based on the first round ratings. Next, although the overall response rate of the survey was close to $50 \%$ it cannot be excluded that hospitals that returned the survey may be different from the ones that did not respond. A risk for selection bias threatening the generalizability of the results is therefore present. However, one could argue that, given the scope of the survey, hospitals that have implemented more of the care models, would be more likely to participate in the study. This would mean that the implementation results are slightly overestimated. This consideration should be taken into account while interpreting the results. Lastly, the responses are self-reported, could not be verified and may therefore not entirely reflect the reality of daily practice in the hospitals.

In conclusion, the findings of this cross-sectional survey study in eight European countries demonstrate that despite the current evidence for several CGA-based models of care, there is still a long way to go in terms of further scaling up and working toward system sustainability in most European countries, but that initiatives are being taken. Having a political framework facilitates and speeds up the implementation of geriatric care models of older adults, but sufficient capacity in terms of geriatricians or geriatric specialists needs to be available to run the operational activities that are inherent to implementing these models of care.

\section{Conflict of interest}

None to report. 


\section{REFERENCES}

1. Rubenstein $L Z$, Stuck $A E$, Siu $A L$, Wieland D. Impacts of geriatric evaluation and management programs on defined outcomes: overview of the evidence. J Am Geriatr Soc. 1991;39(9 Pt 2):8S16S; discussion 7S-8S.

2. Buurman BM, Hoogerduijn JG, de Haan RJ, Abu-Hanna A, Lagaay AM, Verhaar HJ et al. Geriatric conditions in acutely hospitalized older patients: prevalence and one-year survival and functional decline. PLoS One. 2011;6(11):e26951. doi:10.1371/journal.pone.0026951.

3. Inouye SK, Studenski S, Tinetti ME, Kuchel GA. Geriatric syndromes: clinical, research, and policy implications of a core geriatric concept. J Am Geriatr Soc. 2007;55(5):780-91. doi:10.1111/j.1532-5415.2007.01156.x.

4. Amador LF, Reed D, Lehman CA. The acute care for elders unit: taking the rehabilitation model into the hospital setting. Rehabil Nurs. 2007;32(3):126-32.

5. Baztan JJ, Suarez-Garcia FM, Lopez-Arrieta J, Rodriguez-Manas L, Rodriguez-Artalejo F.

Effectiveness of acute geriatric units on functional decline, living at home, and case fatality among older patients admitted to hospital for acute medical disorders: meta-analysis. BMJ. 2009;338:b50. doi: $10.1136 /$ bmj.b50.

6. Fox MT, Persaud M, Maimets I, O'Brien K, Brooks D, Tregunno D et al. Effectiveness of acute geriatric unit care using acute care for elders components: a systematic review and meta-analysis. J Am Geriatr Soc. 2012;60(12):2237-45. doi:10.1111/jgs.12028.

7. Ellis G, Gardner M, Tsiachristas A, Langhorne P, Burke O, Harwood RH et al. Comprehensive geriatric assessment for older adults admitted to hospital. Cochrane Database Syst Rev.

2017;9:CD006211. doi:10.1002/14651858.CD006211.pub3.

8. Van Craen K, Braes T, Wellens N, Denhaerynck K, Flamaing J, Moons P et al. The effectiveness of inpatient geriatric evaluation and management units: a systematic review and meta-analysis. J Am Geriatr Soc. 2010;58(1):83-92. doi:10.1111/j.1532-5415.2009.02621.x.

9. Deschodt M, Flamaing J, Haentjens P, Boonen S, Milisen K. Impact of geriatric consultation teams on clinical outcome in acute hospitals: a systematic review and meta-analysis. BMC Med. 2013;11:48. doi:10.1186/1741-7015-11-48.

10. Ellis G, Whitehead MA, Robinson D, O'Neill D, Langhorne P. Comprehensive geriatric assessment for older adults admitted to hospital: meta-analysis of randomised controlled trials. BMJ. 2011;343:d6553. doi:10.1136/bmj.d6553.

11. Deschodt M, Claes V, Van Grootven B, Milisen K, Boland B, Flamaing J et al. Comprehensive geriatric care in hospitals: the role of inpatient geriatric consultation teams. Brussels: Health Services Research (HSR) - Belgian Health Care Knowledge Centre (KCE)2015. Report No.: KCE Reports 245Cs. D/2015/10.273/47.

12. Grigoryan KV, Javedan $\mathrm{H}$, Rudolph JL. Orthogeriatric care models and outcomes in hip fracture patients: a systematic review and meta-analysis. J Orthop Trauma. 2014;28(3):e49-55.

doi:10.1097/BOT.0b013e3182a5a045.

13. Sennour Y, Counsell SR, Jones J, Weiner M. Development and implementation of a proactive geriatrics consultation model in collaboration with hospitalists. J Am Geriatr Soc.

2009;57(11):2139-45. doi:10.1111/j.1532-5415.2009.02496.x.

14. Van Grootven B, Flamaing J, Dierckx de Casterle B, Dubois C, Fagard K, Herregods MC et al. Effectiveness of in-hospital geriatric co-management: a systematic review and meta-analysis. Age Ageing. 2017;46(6):903-10. doi:10.1093/ageing/afx051.

15. Ellis G, Marshall T, Ritchie C. Comprehensive geriatric assessment in the emergency department. Clin Interv Aging. 2014;9:2033-43. doi:10.2147/CIA.S29662.

16. Southerland LT, Vargas AJ, Nagaraj L, Gure TR, Caterino JM. An Emergency Department Observation Unit Is a Feasible Setting for Multidisciplinary Geriatric Assessments in Compliance With the Geriatric Emergency Department Guidelines. Acad Emerg Med. 2018;25(1):76-82. doi: $10.1111 /$ acem.13328.

17. Lowthian JA, McGinnes RA, Brand CA, Barker AL, Cameron PA. Discharging older patients from the emergency department effectively: a systematic review and meta-analysis. Age Ageing. 2015;44(5):761-70. doi:10.1093/ageing/afv102.

18. Ahmed N, Taylor K, McDaniel Y, Dyer CB. The role of an Acute Care for the Elderly unit in achieving hospital quality indicators while caring for frail hospitalized elders. Popul Health Manag. 2012;15(4):236-40. doi:10.1089/pop.2011.0055.

19. Di Bari M, Balzi D, Roberts AT, Barchielli A, Fumagalli S, Ungar A et al. Prognostic stratification of older persons based on simple administrative data: development and validation of the "Silver Code," to be used in emergency department triage. J Gerontol A Biol Sci Med Sci. 2010;65(2):15964. doi:10.1093/gerona/glp043. 
20. Lampela P, Hartikainen S, Lavikainen P, Sulkava R, Huupponen R. Effects of medication assessment as part of a comprehensive geriatric assessment on drug use over a 1-year period: a population-based intervention study. Drugs Aging. 2010;27(6):507-21. doi:10.2165/11536650$000000000-00000$.

21. Tulner LR, van Campen JP, Frankfort SV, Koks CH, Beijnen JH, Brandjes DP et al. Changes in under-treatment after comprehensive geriatric assessment: an observational study. Drugs Aging. 2010;27(10):831-43. doi:10.2165/11539330-000000000-00000.

22. Lynn MR. Determination and quantification of content validity. Nurs Res. 1986;35(6):382-5. 23. Polit DF, Beck CT, Owen SV. Is the CVI an acceptable indicator of content validity? Appraisal and recommendations. Res Nurs Health. 2007;30(4):459-67. doi:10.1002/nur.20199.

24. Malone M, Capezuti E, RM P. Acute Care for Elders: A Model for Interdisciplinary Care. New York, United States of America: Humana Press; 2014.

25. Koninklijk Besluit 29 januari 2007 houdende vaststelling eensdeels, van de normen waaraan het zorgprogramma voor de geriatrische patiënt moet voldoen om te worden erkend en, anderdeels, van bijzondere aanvullende normen voor de erkenning van ziekenhuizen en ziekenhuisdiensten (tekstbijwerking 18-04-2014), (2014).

26. Styrket Indsats for den Ældre Medicinske Patient. National Handlingsplan 2016. København, Denmark2016.

27. National Clinical Programme For Older People - Specialist Geriatric Services Model of Care. 2012.

28. Zdravje RSMZ. 999. Resolucija o nacionalnem planu zdravstvenega varstva 2016-2025 »Skupaj za družbo zdravja«(ReNPZV16-25), stran 3407. 2016. https://www.uradni-list.si/glasilouradni-list-rs/vsebina/2016-01-0999?sop=2016-01-0999. Accessed 19 June 2018.

29. Circulaire DHOS/O2/DGS/SD. 5D/2002/157 du 18 mars 2002 relative à I'amélioration de la filière de soins gériatriques, (2002).

30. Circulaire relative à l'améloration de la filière de soins gériatrique (DHOS/02/2007/117), (2007).

31. Gezamenlijke Ouderenbonden Unie KBO P, NVOG en NOOM. Kwaliteitsaspecten en normering keurmerk Seniorvriendelijk Ziekenhuis 2017. 2016. https://www.kbo-pcob.nl/wpcontent/uploads/2017/10/Kwaliteitsaspecten-en-normering-keurmerk-SeniorvriendelijkZiekenhuis-2017-.pdf.

32. Reiter R, Diraoui S, Van Den Noortgate N, Cruz-Jentoft AJ, EAMA, Geriatric XEPC. How to become a Geriatrician in different European countries. Eur Geriatr Med. 2014;5(5):347-51. doi: $10.1016 /$ j.eurger.2014.07.008.

33. Dimensioneringsplan 2018-2020, introduktions- og hoveduddannelsesforløb i speciallægeuddannelsen. København, Denmark: Sundhedsstyrelsen 2017. 
Table 1. General characteristics about respondents and hospitals

\begin{tabular}{|c|c|c|c|c|c|c|c|c|c|}
\hline & $\begin{array}{c}\text { Total } \\
N=178\end{array}$ & $\begin{array}{l}\text { Belgium } \\
N=69\end{array}$ & $\begin{array}{c}\text { Denmark } \\
\mathrm{N}=\mathbf{2 2}\end{array}$ & $\begin{array}{c}\text { Estonia } \\
\mathrm{N}=13\end{array}$ & $\begin{array}{l}\text { Greece } \\
\mathrm{N}=47\end{array}$ & $\begin{array}{c}\text { Iceland } \\
\mathrm{N}=4\end{array}$ & $\begin{array}{l}\text { Ireland } \\
\mathrm{N}=11\end{array}$ & $\begin{array}{l}\text { Malta } \\
\mathrm{N}=3\end{array}$ & $\begin{array}{l}\text { Slovenia } \\
\mathbf{N}=9\end{array}$ \\
\hline Response rate & $50 \%$ & $72 \%$ & $100 \%$ & $72 \%$ & $27 \%$ & $67 \%$ & $50 \%$ & $75 \%$ & $96 \%$ \\
\hline \multicolumn{10}{|l|}{ Respondent } \\
\hline Female, n (\%) & $100(56.2)$ & $28(40.6)$ & $8(36.4)$ & $1(7.7)$ & $23(48.9)$ & $3(75.0)$ & $9(81.8)$ & $2(66.7)$ & $4(44.4)$ \\
\hline Age, mean (SD) & $48.9(9.8)$ & $47.0(10.0)$ & $50.1(10.5)$ & $55.9(7.1)$ & $48.6(10.3)$ & $56.3(9.2)$ & $46.7(7.1)$ & $48.3(3.1)$ & $50.4(6.5)$ \\
\hline \begin{tabular}{ll}
\multicolumn{2}{l}{ Profession, $\mathrm{n}(\%)$} \\
- & Geriatrician \\
- & Internal medicine physician \\
- & Head nurse \\
- & Geriatric nurse \\
- & Other type of physician \\
- & Paramedic \\
- & Nurse \\
\end{tabular} & $\begin{array}{l}84(47.2) \\
40(22.5) \\
13(7.3) \\
7(3.9) \\
18(10.1) \\
5(2.8) \\
11(6.2) \\
\end{array}$ & $\begin{array}{l}52(75.4) \\
0 \\
9(13.0) \\
5(7.2) \\
0 \\
3(4.3) \\
0 \\
\end{array}$ & $\begin{array}{l}15(68.2) \\
5(22.7) \\
0 \\
0 \\
2(9.1) \\
0 \\
0 \\
\end{array}$ & $\begin{array}{l}1(7.7) \\
3(23.1) \\
1(7.7) \\
2(15.4) \\
4(30.8) \\
1(7.7) \\
1(7.7) \\
\end{array}$ & $\begin{array}{l}1(2.1) \\
26(55.3) \\
3(6.4) \\
0 \\
6(12.8) \\
1(2.1) \\
10(21.3) \\
\end{array}$ & $\begin{array}{l}2(50.0) \\
1(25.0) \\
0 \\
0 \\
1(25.0) \\
0 \\
0 \\
\end{array}$ & $\begin{array}{l}11(100) \\
0 \\
0 \\
0 \\
0 \\
0 \\
0 \\
\end{array}$ & $\begin{array}{l}2(66.7) \\
0 \\
0 \\
0 \\
1(33.3) \\
0 \\
0 \\
\end{array}$ & $\begin{array}{l}0 \\
5(55.6) \\
0 \\
0 \\
4(44.4) \\
0 \\
0 \\
\end{array}$ \\
\hline \multicolumn{10}{|l|}{ Hospital } \\
\hline $\begin{array}{ll}\text { Type, } \mathrm{n}(\%) \\
- & \text { General } \\
- & \text { University } \\
- & \text { General + university }\end{array}$ & $\begin{array}{l}132(74.2) \\
36(20.2) \\
10(5.6) \\
\end{array}$ & $\begin{array}{l}56(81.2) \\
10(14.5) \\
3(4.3) \\
\end{array}$ & $\begin{array}{l}12(54.5) \\
9(40.9) \\
1(4.5) \\
\end{array}$ & $\begin{array}{l}11(84.6) \\
1(7.7) \\
0 \\
\end{array}$ & $\begin{array}{l}38(80.9) \\
5(10.6) \\
4(8.5) \\
\end{array}$ & $\begin{array}{l}2(50.0) \\
1(25.0) \\
1(25.0) \\
\end{array}$ & $\begin{array}{l}3(27.3) \\
7(63.6) \\
1(9.1) \\
\end{array}$ & $\begin{array}{l}2(66.7) \\
1(33.3) \\
0\end{array}$ & $\begin{array}{l}7(77.8) \\
2(22.2) \\
0\end{array}$ \\
\hline Beds $^{1}$, median (Q1-Q3) & $\begin{array}{l}350 \\
(197-577)\end{array}$ & $\begin{array}{l}420 \\
(268-715)\end{array}$ & $\begin{array}{l}373 \\
(243-600) \\
\end{array}$ & $\begin{array}{l}150 \\
(101-322)\end{array}$ & $\begin{array}{l}250 \\
(140-435)\end{array}$ & $\begin{array}{l}70 \\
(24-516)\end{array}$ & $\begin{array}{l}285 \\
(230-500) \\
\end{array}$ & $\begin{array}{l}300 \\
(40-\ldots)\end{array}$ & $\begin{array}{l}350 \\
(150-1010)\end{array}$ \\
\hline Geriatricians in hospital, n (\%) & $106(59.6)$ & $68(98.6)$ & $19(86.4)$ & $3(23.1)$ & $2(4.3)$ & $2(50.0)$ & $11(100.0)$ & $1(33.3)$ & 0 \\
\hline $\begin{array}{ll}- & \mathrm{N}, \text { median }(\mathrm{Q} 1-\mathrm{Q} 3) \\
- & \mathrm{FTE} \text { median (Q1-Q3) } \\
\end{array}$ & $\begin{array}{l}3(2-5) \\
2.7(1.8-4.0)\end{array}$ & $\begin{array}{l}3(2-4) \\
2.6(1.8-3.8)\end{array}$ & $\begin{array}{l}5(3-8) \\
4(2.3-7.5)\end{array}$ & $\begin{array}{l}1(1-2) \\
1(0.6-1.0)\end{array}$ & $\begin{array}{l}3(1-\ldots) \\
1.5(1.0-\ldots)\end{array}$ & $\begin{array}{l}9.5(2-\ldots) \\
7(2.0-7.0)\end{array}$ & $\begin{array}{l}3(2-6) \\
3(2.0-4.8)\end{array}$ & $\begin{array}{l}6(6-6) \\
2(2.0-2.0)\end{array}$ & NA \\
\hline $\begin{array}{l}\text { In case no geriatricians, internist } \\
\text { with geriatric expertise, } \mathrm{n} / \mathrm{N}(\%)\end{array}$ & $5 / 72(6.9)$ & $0 / 1(0)$ & $1 / 3(33.3)$ & $2 / 10(20.2)$ & $2 / 45(4.4)$ & $0 / 2(0)$ & NA & $0 / 2(0)$ & $0 / 9(0)$ \\
\hline
\end{tabular}

${ }^{1}$ excluding day clinics and emergency department; $N A=$ not applicable; $S D=$ standard deviation 
Table 2. Implementation of CGA-based models of care

\begin{tabular}{|c|c|c|c|c|c|c|c|c|c|}
\hline & $\begin{array}{c}\text { Total } \\
\mathrm{N}=178\end{array}$ & $\begin{array}{c}\text { Belgium } \\
N=69\end{array}$ & $\begin{array}{c}\text { Denmark } \\
\mathrm{N}=\mathbf{2 2}\end{array}$ & $\begin{array}{c}\text { Estonia } \\
\mathbf{N}=13\end{array}$ & $\begin{array}{l}\text { Greece } \\
\mathbf{N}=47\end{array}$ & $\begin{array}{c}\text { Iceland } \\
\mathbf{N}=4\end{array}$ & $\begin{array}{c}\text { Ireland } \\
\mathbf{N}=11\end{array}$ & $\begin{array}{c}\text { Malta } \\
\mathrm{N}=3\end{array}$ & $\begin{array}{c}\text { Slovenia } \\
\mathbf{N}=\mathbf{9}\end{array}$ \\
\hline Acute geriatric units, $\mathrm{n}(\%)$ & $92(51.6)$ & $69(100.0)$ & $16(72.7)$ & 0 & $1(2.1)$ & $1(25.0)$ & $4(36.4)$ & 0 & $1(11.1)$ \\
\hline Number of beds, median (Q1-Q3) & $50(28-78)$ & $60(36-86)$ & $20(26-34)$ & NA & 60 & 20 & $33(16-56)$ & NA & 16 \\
\hline Mean length of stay, median (Q1-Q3) & $13(10-17)$ & $14(12-17)$ & $7(5-8)$ & NA & 30 & 15 & $13(10-18)$ & NA & 7 \\
\hline Geriatric rehabilitation unit, $\mathrm{n}(\%)$ & $41(23)$ & $21(30.4)$ & $5(22.7)$ & $2(15.4)$ & $2(4.3)$ & $3(75.0)$ & $7(63.6)$ & 0 & $1(11.1)$ \\
\hline Number of beds, median (Q1-Q3) & $22(10.5-30)$ & $24(20.5-31)$ & $15(8-20.5)$ & $5(5-5)$ & - & $17(4-80)$ & $20(13-34)$ & NA & 30 \\
\hline Geriatric consultation team, n (\%) & $97(54.5)$ & $69(100)$ & $13(59.1)$ & $3(23.1)$ & $2(4.3)$ & $1(25.0)$ & $8(72.7)$ & $1(33.3)$ & 0 \\
\hline 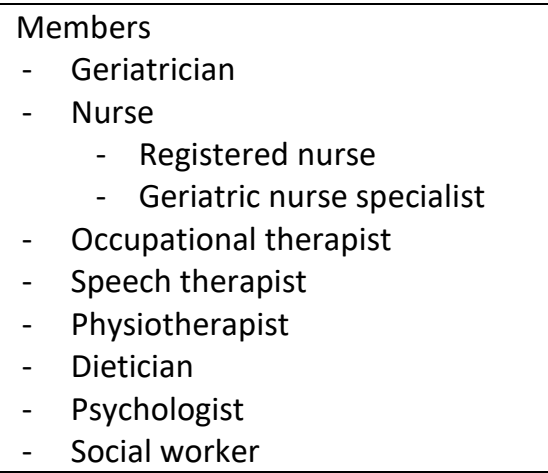 & $\begin{array}{l}95(97.9) \\
85(87.6) \\
-38(39.2) \\
-75(77.3) \\
62(63.9) \\
50(51.5) \\
46(47.4) \\
45(46.4) \\
40(41.2) \\
36(37.1)\end{array}$ & $\begin{array}{l}68(98.6) \\
67(97.1) \\
-31(44.9) \\
-63(91.3) \\
55(79.7) \\
46(66.7) \\
33(47.8) \\
41(59.4) \\
39(56.5) \\
32(46.4)\end{array}$ & $\begin{array}{l}0 \\
9(69.2) \\
-1(7.7) \\
-8(61.5) \\
4(30.8) \\
1(7.7) \\
8(61.5) \\
1(7.7) \\
0 \\
0\end{array}$ & $\begin{array}{l}2(66.7) \\
3(100.0) \\
-3(100.0) \\
-1(33.3) \\
1(33.3) \\
2(66.7) \\
2(66.7 \\
1(33.3) \\
1(33.3) \\
3(100.0)\end{array}$ & $\begin{array}{l}2(100.0) \\
1(50.0) \\
-1(50.0) \\
-0 \\
0 \\
0 \\
1(50.0) \\
1(50.0) \\
0 \\
0\end{array}$ & $\begin{array}{l}1(100.0) \\
1(100.0) \\
-1(100.0) \\
-0 \\
0 \\
0 \\
0 \\
0 \\
0 \\
1(100.0)\end{array}$ & $\begin{array}{l}8(100.0) \\
4(50.0) \\
-1(12.5) \\
-3(37.5) \\
2(25.0) \\
1(12.5) \\
2(25.0) \\
1(12.5) \\
0 \\
0\end{array}$ & $\begin{array}{l}1(100) \\
0 \\
-0 \\
-0 \\
0 \\
0 \\
0 \\
0 \\
0 \\
0\end{array}$ & NA \\
\hline $\begin{array}{l}\text { Place of intervention } \\
\text { - } \quad \text { Medical wards } \\
\text { - } \quad \text { Surgical wards } \\
\text { - } \quad \text { Emergency department } \\
\text { - } \quad \text { Ambulatory consultations } \\
\text { - } \quad \text { Day care hospitals } \\
\text { - } \quad \text { Home care } \\
\text { - } \quad \text { Nursing homes }\end{array}$ & $\begin{array}{l}93(95.9) \\
92(94.8) \\
38(39.2) \\
12(12.4) \\
10(10.3) \\
10(10.3) \\
10(10.3)\end{array}$ & $\begin{array}{l}68(98.6) \\
68(98.6) \\
20(29.0) \\
3(4.3) \\
6(8.7) \\
0 \\
0\end{array}$ & $\begin{array}{l}12(92.3) \\
10(76.9) \\
10(76.9) \\
7(53.8) \\
1(7.7) \\
9(69.2) \\
6(46.2) \\
\end{array}$ & $\begin{array}{l}2(66.7) \\
2(66.7) \\
0 \\
0 \\
0 \\
1(33.3) \\
2(66.7)\end{array}$ & $\begin{array}{l}1(50.0) \\
2(100) \\
0 \\
0 \\
1(50.0) \\
0 \\
0\end{array}$ & $\begin{array}{l}1(100) \\
1(100) \\
1(100) \\
0 \\
0 \\
0 \\
0\end{array}$ & $\begin{array}{l}8(100) \\
8(100) \\
7(87.5) \\
2(25.0) \\
225.0) \\
0 \\
2(25.0)\end{array}$ & $\begin{array}{l}1(100) \\
1(100) \\
0 \\
0 \\
0 \\
0 \\
0\end{array}$ & NA \\
\hline Geriatric co-management, $\mathrm{n}(\%)$ & $52(29.2)$ & $28(40.6)$ & $14(63.6)$ & $3(23.1)$ & $2(4.3)$ & 0 & $2(18.2)$ & $3(100)$ & 0 \\
\hline $\begin{array}{l}\text { Members } \\
-\quad \text { Geriatrician } \\
\text { - Internal medicine physician } \\
\text { - Nurse } \\
\text { - } \text { Registered nurse } \\
\text { - } \text { Geriatric nurse specialist }\end{array}$ & $\begin{array}{l}45(86.5) \\
15(28.8) \\
39(75) \\
-25(48.1) \\
-31(59.6) \\
\end{array}$ & $\begin{array}{l}27(96.4) \\
9(32.1) \\
21(75.0) \\
-16(57.1) \\
-19(67.9) \\
\end{array}$ & $\begin{array}{l}13(92.9) \\
3(21.4) \\
11(78.6) \\
-2(14.3) \\
-11(78.6)\end{array}$ & $\begin{array}{l}1(33.3) \\
2(66.7) \\
3(100.0) \\
-3(100.0) \\
-0\end{array}$ & $\begin{array}{l}0 \\
0 \\
1(50.0) \\
-1(50.0) \\
-0\end{array}$ & NA & $\begin{array}{l}2(100.0) \\
0 \\
1(50.0) \\
-1(50.0) \\
-1(50.0)\end{array}$ & $\begin{array}{l}2(66.7) \\
1(33.3) \\
2(66.7) \\
-2(66.7) \\
-0\end{array}$ & NA \\
\hline
\end{tabular}




\begin{tabular}{|c|c|c|c|c|c|c|c|c|c|}
\hline $\begin{array}{ll}\text { - } & \text { Physiotherapist } \\
\text { - } & \text { Occupational therapist } \\
\text { - } & \text { Social worker } \\
\text { - } & \text { Dietician } \\
\text { - } & \text { Speech therapist } \\
\text { - } & \text { Psychologist } \\
\end{array}$ & $\begin{array}{l}32(61.5) \\
31(59.6) \\
22(42.3) \\
15(28.8) \\
15(28.8) \\
13(25) \\
\end{array}$ & $\begin{array}{l}14(50.0) \\
19(67.9) \\
15(53.6) \\
10(35.7) \\
10(35.7) \\
9(32.1) \\
\end{array}$ & $\begin{array}{l}10(71.4) \\
7(50.0) \\
0 \\
2(14.3) \\
1(7.1) \\
0 \\
\end{array}$ & $\begin{array}{l}2(66.7) \\
2(66.7) \\
3(100.0) \\
1(33.3) \\
2(66.7) \\
1(33.3) \\
\end{array}$ & $\begin{array}{l}2(100.0) \\
0 \\
2(100.0) \\
1(50.0) \\
0 \\
1(50.0) \\
\end{array}$ & & $\begin{array}{l}2(100.0) \\
1(50.0) \\
1(50.0) \\
1(50.0) \\
1(50.0) \\
1(50.0)\end{array}$ & $\begin{array}{l}2(66.7) \\
2(66.7) \\
1(33.3) \\
3(100.0) \\
1(33.3) \\
1(33.3) \\
\end{array}$ & \\
\hline Emergency department & $173(97.2)$ & $68(98.6)$ & $22(100)$ & $13(100)$ & $45(95.7)$ & $4(100)$ & $10(90.9)$ & $3(100)$ & $8(88.9)$ \\
\hline Geriatrician at the ED & $100(57.8)$ & $48(70.6)$ & $17(77.3)$ & $1(7.7)$ & $4(8.5)$ & $3(75.0)$ & $8(80.0)$ & $1(33.3)$ & 0 \\
\hline $\begin{array}{l}\text { Frequency } \\
\text { - } \quad \text { Every day of the week } \\
\text { - } \quad \text { Often } \\
\text { - } \quad \text { Upon request }\end{array}$ & $\begin{array}{l}23(23.0) \\
26(26.0) \\
51(51.0) \\
\end{array}$ & $\begin{array}{l}1(2.1) \\
12(25.0) \\
35(72.9) \\
\end{array}$ & $\begin{array}{l}3(17.6) \\
8(47.1) \\
6(35.3)\end{array}$ & $\begin{array}{l}0 \\
0 \\
1(100) \\
\end{array}$ & $\begin{array}{l}0 \\
1(25.0) \\
3(75.0)\end{array}$ & $\begin{array}{l}1(33.3) \\
0 \\
2(66.7)\end{array}$ & $\begin{array}{l}1(12.5) \\
5(62.5) \\
2(25.0)\end{array}$ & $\begin{array}{l}0 \\
0 \\
1(33.3) \\
\end{array}$ & NA \\
\hline Boxes for older people at ED & $9(5.2)$ & $4(5.9)$ & $1(4.5)$ & 0 & $3(6.4)$ & 0 & $1(10.0)$ & 0 & 0 \\
\hline Number of boxes, median (Q1-Q3) & $2(1-4)$ & $\begin{array}{l}2.5(1.25- \\
4.5)\end{array}$ & $5(5-5)$ & NA & $1(1-\ldots)$ & 0 & $1(1-1)$ & NA & NA \\
\hline Systematic screening (“yes") & $62(35.8)$ & $45(66.2)$ & $5(22.7)$ & 0 & $5(10.6)$ & $1(25.0)$ & $6(60.0)$ & 0 & 0 \\
\hline \begin{tabular}{ll}
\multicolumn{2}{l}{ Type of screening } \\
- & TRST \\
- & GRP \\
- & ISAR \\
- & interRAI ED \\
- & Other \\
\end{tabular} & $\begin{array}{l}7(11.3) \\
21(33.9) \\
23(37.1) \\
3(4.8) \\
8(12.9)\end{array}$ & $\begin{array}{l}0 \\
21(46.7) \\
22(48.9) \\
1(2.2) \\
1(2.2)\end{array}$ & $\begin{array}{l}0 \\
0 \\
1(20.0) \\
0 \\
4(80.0)\end{array}$ & NA & $\begin{array}{l}4(80.0) \\
0 \\
0 \\
1(20.0) \\
0\end{array}$ & $\begin{array}{l}0 \\
0 \\
0 \\
1(100) \\
0\end{array}$ & $\begin{array}{l}3(50.0) \\
0 \\
0 \\
0 \\
3(50.0)\end{array}$ & NA & NA \\
\hline \multicolumn{10}{|l|}{ Ambulatory services } \\
\hline Geriatric day clinic, $\mathrm{n}(\%)$ & $62(34.8)$ & $53(76.8)$ & $5(22.7)$ & 0 & 0 & $1(25.0)$ & $3(27.3)$ & 0 & 0 \\
\hline \begin{tabular}{ll}
\multicolumn{2}{l}{ Type of facilities } \\
$-\quad$ Diagnostic facility \\
- & Therapeutic facility \\
- & Rehabilitation facility
\end{tabular} & $\begin{array}{l}60(96.8) \\
60(96.8) \\
32(51.6) \\
\end{array}$ & $\begin{array}{l}52(98.1) \\
52(98.1) \\
28(40.6)\end{array}$ & $\begin{array}{l}5(100) \\
4(80.0) \\
0\end{array}$ & NA & NA & $\begin{array}{l}1(100) \\
1(100) \\
1(100)\end{array}$ & $\begin{array}{l}2(66.7) \\
3(100) \\
3(100)\end{array}$ & NA & NA \\
\hline Memory clinic & $100(56.2)$ & $62(89.9)$ & $12(54.5)$ & $1(7.7)$ & $14(29.8)$ & $2(50.0)$ & $8(72.7)$ & 0 & $1(11.1)$ \\
\hline Falls prevention clinic & $86(48.3)$ & $55(79.7)$ & $16(72.7)$ & $4(30.8)$ & $1(2.1)$ & $1(25.0)$ & $7(63.6)$ & $1(33.3)$ & $1(11.1)$ \\
\hline Transitional care programs & $107(60.1)$ & $52(75.4)$ & $15(68.2)$ & $10(76.9)$ & $16(34.0)$ & $3(75.0)$ & $6(54.5)$ & $2(66.7)$ & $3(33.3)$ \\
\hline
\end{tabular}

$N A=$ not applicable; ED = emergency department; GRP = Geriatric Risk Profile; TRST = Triage Risk Screening Tools; ISAR = Identification for Seniors at Risk 
Table 3. Intention to implement CGA-based models of care in hospitals were care model is not present

\begin{tabular}{|c|c|c|c|c|c|c|c|c|c|}
\hline $\begin{array}{l}\text { Intention to implement ... } \\
\text { N (\%) }\end{array}$ & $\begin{array}{c}\text { Total } \\
N=178\end{array}$ & $\begin{array}{l}\text { Belgium } \\
N=69\end{array}$ & $\begin{array}{c}\text { Denmark } \\
\mathrm{N}=\mathbf{2 2}\end{array}$ & $\begin{array}{l}\text { Estonia } \\
\mathrm{N}=13\end{array}$ & $\begin{array}{l}\text { Greece } \\
N=47\end{array}$ & $\begin{array}{c}\text { Iceland } \\
\mathbf{N}=4\end{array}$ & $\begin{array}{l}\text { Ireland } \\
\mathrm{N}=11\end{array}$ & $\begin{array}{l}\text { Malta } \\
\mathrm{N}=3\end{array}$ & $\begin{array}{c}\text { Slovenia } \\
\mathrm{N}=9\end{array}$ \\
\hline $\begin{array}{cl}\text { Acute } & \text { geriatric units } \\
- & \text { No } \\
- & \text { In next year? } \\
- & \text { In next } 5 \text { years? }\end{array}$ & $\begin{array}{l}67(77.9) \\
4(4.7) \\
15(17.4)\end{array}$ & NA & $\begin{array}{l}4(66.7) \\
2(9.1) \\
0\end{array}$ & $\begin{array}{l}12(92.3) \\
0 \\
1(7.7)\end{array}$ & $\begin{array}{l}41(89.1) \\
0 \\
5(10.9)\end{array}$ & $\begin{array}{l}2(66.7) \\
0 \\
1(33.3)\end{array}$ & $\begin{array}{l}2(28.6) \\
2(28.6) \\
3(42.9)\end{array}$ & $\begin{array}{l}2(66.7) \\
0 \\
1(33.3)\end{array}$ & $\begin{array}{l}4(50.0) \\
0 \\
4(50.0)\end{array}$ \\
\hline $\begin{array}{c}\text { Geriatric rehabilitation unit } \\
-\quad \text { No } \\
-\quad \text { In next year? } \\
-\quad \text { In next } 5 \text { years? }\end{array}$ & $\begin{array}{l}120(87.6) \\
1(0.7) \\
16(11.7)\end{array}$ & $\begin{array}{l}41(85.4) \\
0 \\
7(14.6)\end{array}$ & $\begin{array}{l}17(100) \\
0 \\
0\end{array}$ & $\begin{array}{l}10(90.9) \\
0 \\
1(9.1)\end{array}$ & $\begin{array}{l}40(85.1) \\
0 \\
5(11.1)\end{array}$ & $\begin{array}{l}1(100) \\
0 \\
0\end{array}$ & $\begin{array}{l}3(75.0) \\
0 \\
1(25.0)\end{array}$ & $\begin{array}{l}2(66.7) \\
0 \\
1(33.3)\end{array}$ & $\begin{array}{l}6(75.0) \\
1(12.5) \\
1(12.5)\end{array}$ \\
\hline $\begin{array}{cl}\text { Geriatric consultation team } \\
-\quad \text { No } \\
-\quad \text { In next year? } \\
-\quad \text { In next } 5 \text { years? }\end{array}$ & $\begin{array}{l}65(80.2) \\
3(3.7) \\
13(16.0)\end{array}$ & NA & $\begin{array}{l}6(66.7) \\
1(11.1) \\
2(22.2)\end{array}$ & $\begin{array}{l}10(100.0) \\
0 \\
0\end{array}$ & $\begin{array}{l}40(88.9) \\
0 \\
5(11.1)\end{array}$ & $\begin{array}{l}2(66.7) \\
0 \\
1(33.3)\end{array}$ & $\begin{array}{l}1(33.3) \\
1(33.3) \\
1(33.3)\end{array}$ & $\begin{array}{l}1(50.0) \\
1(50.0) \\
0\end{array}$ & $\begin{array}{l}5(55.6) \\
0 \\
4(44.4)\end{array}$ \\
\hline $\begin{array}{cl}\text { Geriatric co-management } \\
-\quad \text { No } \\
-\quad \text { In next year? } \\
-\quad \text { In next } 5 \text { years? }\end{array}$ & $\begin{array}{l}81(64.2) \\
14(11.1) \\
32(25.4)\end{array}$ & $\begin{array}{l}17(41.5) \\
8(19.5) \\
16(39.0)\end{array}$ & $\begin{array}{l}5(62.5) \\
2(25.0) \\
1(12.5)\end{array}$ & $\begin{array}{l}10(100.0) \\
0 \\
0\end{array}$ & $\begin{array}{l}38(84.4) \\
0 \\
7(15.6)\end{array}$ & $\begin{array}{l}2(50.0) \\
0 \\
2(50.0)\end{array}$ & $\begin{array}{l}3(33.3) \\
4(44.4) \\
2(22.2)\end{array}$ & NA & $\begin{array}{l}5(55.6) \\
0 \\
4(44.4)\end{array}$ \\
\hline $\begin{array}{cl}\text { Geriatric ED boxes } \\
- & \text { No } \\
- & \text { In next year? } \\
- & \text { In next } 5 \text { years? }\end{array}$ & $\begin{array}{l}126(76.8) \\
9(5.5) \\
29(17.9)\end{array}$ & $\begin{array}{l}48(75.0) \\
1(1.6) \\
15(23.4)\end{array}$ & $\begin{array}{l}13(61.9) \\
4(19.0) \\
4(19.0)\end{array}$ & $\begin{array}{l}13(100.0) \\
0 \\
0\end{array}$ & $\begin{array}{l}36(85.7) \\
1(2.4) \\
5(11.9)\end{array}$ & $\begin{array}{l}3(75.0) \\
0 \\
1(25.0)\end{array}$ & $\begin{array}{l}5(55.6) \\
2(22.2) \\
2(22.2)\end{array}$ & $\begin{array}{l}2(66.7) \\
0 \\
1(33.3)\end{array}$ & $\begin{array}{l}6(75.0) \\
1(12.5) \\
1(12.5)\end{array}$ \\
\hline \begin{tabular}{cl}
\multicolumn{2}{l}{ Screening of older patients at ED } \\
$-\quad$ No \\
$-\quad$ In next year? \\
$-\quad$ In next 5 years?
\end{tabular} & $\begin{array}{l}74(63.7) \\
14(12.1) \\
28(24.1) \\
\end{array}$ & $\begin{array}{l}6(25.0) \\
7(29.2) \\
11(45.8) \\
\end{array}$ & $\begin{array}{l}9(52.9) \\
3(17.6) \\
5(29.4)\end{array}$ & $\begin{array}{l}13(100.0) \\
0 \\
0\end{array}$ & $\begin{array}{l}37(88.1) \\
1(2.4) \\
4(9.5)\end{array}$ & $\begin{array}{l}2(66.7) \\
0 \\
1(33.3)\end{array}$ & $\begin{array}{l}1(20.0) \\
2(40.0) \\
2(40.0)\end{array}$ & $\begin{array}{l}2(66.7) \\
0 \\
1(33.3)\end{array}$ & $\begin{array}{l}4(44.4) \\
1(11.1) \\
4(44.4)\end{array}$ \\
\hline \begin{tabular}{cl}
\multicolumn{2}{l}{ Geriatric day clinic? } \\
$-\quad$ No \\
$-\quad$ In next year? \\
$-\quad$ In next 5 years?
\end{tabular} & $\begin{array}{l}102(87.9) \\
2(1.1) \\
12(10.3)\end{array}$ & $\begin{array}{l}15(93.8) \\
0 \\
1(6.3)\end{array}$ & $\begin{array}{l}14(82.4) \\
1(5.9) \\
2(11.8)\end{array}$ & $\begin{array}{l}13(100.0) \\
0 \\
0\end{array}$ & $\begin{array}{l}41(87.2) \\
1(2.1) \\
5(10.6)\end{array}$ & $\begin{array}{l}2(66.7) \\
0 \\
1(33.3)\end{array}$ & $\begin{array}{l}7(87.5) \\
0 \\
1(12.5)\end{array}$ & $\begin{array}{l}3(100.0) \\
0 \\
0\end{array}$ & $\begin{array}{l}7(77.8) \\
0 \\
2(22.2)\end{array}$ \\
\hline $\begin{array}{cl}\text { Transitional care programs } \\
-\quad \text { No } \\
-\quad \text { In next year? } \\
-\quad \text { In next } 5 \text { years? }\end{array}$ & $\begin{array}{l}50(70.4) \\
8(11.3) \\
13(18.3)\end{array}$ & $\begin{array}{l}9(52.9) \\
4(23.5) \\
4(23.5)\end{array}$ & $\begin{array}{l}4(57.1) \\
1(14.3) \\
2(28.6)\end{array}$ & $\begin{array}{l}3(100.0) \\
0 \\
0\end{array}$ & $\begin{array}{l}29(93.5) \\
0 \\
2(6.5)\end{array}$ & $\begin{array}{l}0 \\
0 \\
1(100.0)\end{array}$ & $\begin{array}{l}1(20.0) \\
2(40.0) \\
2(40.0)\end{array}$ & $\begin{array}{l}0 \\
0 \\
1(100.0)\end{array}$ & $\begin{array}{l}4(66.7) \\
1(16.7) \\
1(16.7)\end{array}$ \\
\hline
\end{tabular}


Supplementary material: Item-Content Validity Index, Modified Kappa and Comprehensiveness of questions

\begin{tabular}{|c|c|c|c|c|c|c|}
\hline Question & $\begin{array}{l}\text { N experts } \\
\text { score 'Yes' }\end{array}$ & $\begin{array}{c}\text { N experts score } \\
\text { ' } 3 \text { ' or ' } 4 \text { ' }\end{array}$ & $\mathbf{I}-\mathrm{CVI} \mathbf{a}^{\mathrm{a}}$ & $\mathbf{P}{ }^{b}$ & $\begin{array}{l}\text { Kappa } \\
\text { score }^{c}\end{array}$ & Conclusion $^{d}$ \\
\hline 1 Name of your hospital & 11 & 9 & 0.82 & 0.027 & 0.813 & Accepted \\
\hline 2 City/Country & 11 & 10 & 0.91 & 0.005 & 0.909 & Accepted \\
\hline 3 Type of hospital & 8 & 11 & 1.00 & 0.000 & 1.000 & Accepted \\
\hline 4 Total number of beds on hospital wards & 9 & 10 & 0.91 & 0.005 & 0.909 & Accepted \\
\hline 5 Are there geriatricians at work in your hospital? & 11 & 11 & 1.00 & 0.000 & 1.000 & Accepted \\
\hline 5 yes a How many? & 8 & 9 & 0.91 & 0.027 & 0.813 & Accepted \\
\hline 5 yes $b$ Number of FTE? & 10 & 10 & 0.91 & 0.005 & 0.909 & Accepted \\
\hline 5 no Are there internal medicine physicians with geriatric expertise at work in your hospital? & 9 & 10 & 0.91 & 0.005 & 0.909 & Accepted \\
\hline 6 Is there an acute geriatric unit at your hospital? & 10 & 11 & 1 & 0.000 & 1.000 & Accepted \\
\hline 6 yes a How many units? & 10 & 10 & 0.91 & 0.005 & 0.909 & Accepted \\
\hline 6 yes b How many beds? & 9 & 10 & 0.91 & 0.005 & 0.909 & Accepted \\
\hline 6 yes $c$ What is the average length of stay? & 10 & 8 & 0.73 & 0.081 & 0.703 & Revised \\
\hline 6 yes $d$ Is there a minimum age for admission? & 10 & 7 & 0.64 & 0.161 & 0.567 & Revised \\
\hline 6 yes e Other conditions for admission? & 9 & 9 & 0.82 & 0.027 & 0.813 & Accepted \\
\hline 6 no Do you intend to implement an acute geriatric unit in your hospital? & 10 & 7 & 0.64 & 0.161 & 0.567 & Revised \\
\hline 7 Is there a geriatric rehabilitation unit (GRU) at your hospital? & 7 & 11 & 1.00 & 0.000 & 1.000 & Accepted \\
\hline 7 yes a How many units? & 10 & 9 & 0.82 & 0.027 & 0.813 & Accepted \\
\hline 7 yes b How many beds? & 11 & 10 & 0.91 & 0.005 & 0.909 & Accepted \\
\hline 7 yes $c$ What is the average length of stay? & 9 & 7 & 0.64 & 0.161 & 0.567 & Revised \\
\hline 7 yes $d$ Conditions for admission? & 10 & 8 & 0.73 & 0.081 & 0.703 & Revised \\
\hline
\end{tabular}




\begin{tabular}{|c|c|c|c|c|c|c|}
\hline 7 no Do you intend to implement a geriatric consultation team in your hospital? & 10 & 8 & 0.73 & 0.081 & 0.703 & Revised \\
\hline 8 Is there a mobile geriatric consultation team at your hospital? & 10 & 11 & 1.00 & 0.000 & 1.000 & Accepted \\
\hline 8 yes a Which are the members of this team? And their FTE? & 9 & 10 & 0.91 & 0.005 & 0.909 & Accepted \\
\hline 8 yes $b$ Where does the geriatric consultation team assess older patients? & 10 & 10 & 0.91 & 0.005 & 0.909 & Accepted \\
\hline 8 no Do you intend to implement a mobile geriatric consultation team in your hospital? & 10 & 8 & 0.73 & 0.081 & 0.703 & Revised \\
\hline 9 Does your hospital use geriatric co-management? & 9 & 10 & 0.91 & 0.005 & 0.909 & Accepted \\
\hline 9 yes Which disciplines are included? & 7 & 10 & 0.91 & 0.005 & 0.909 & Accepted \\
\hline 9 no Do you intend to use geriatric co-management in your hospital? & 10 & 8 & 0.73 & 0.081 & 0.703 & Revised \\
\hline 10 Does your hospital have an emergency department (ED)? & 11 & 9 & 0.82 & 0.027 & 0.813 & Accepted \\
\hline 11 Are there box/rooms in your ED especially designed for treatment of geriatric patients? & 10 & 11 & 1.00 & 0.000 & 1.000 & Accepted \\
\hline 11 yes a How many? & 11 & 9 & 0.82 & 0.027 & 0.813 & Accepted \\
\hline 11 yes $b$ When is there a geriatrician present at the ED? & 10 & 8 & 0.73 & 0.081 & 0.703 & Revised \\
\hline 11 no Do you intend to implement geriatric care boxes at your ED? & 10 & 7 & 0.64 & 0.161 & 0.567 & Revised \\
\hline 12 Are older patients screened for having a geriatric risk profile at your ED? & 10 & 10 & 0.91 & 0.005 & 0.909 & Accepted \\
\hline 12 yes a Which of the following tools do you use? & 11 & 10 & 0.91 & 0.005 & 0.909 & Accepted \\
\hline 12 yes $b$ When are older patients screened? & 9 & 7 & 0.64 & 0.161 & 0.567 & Revised \\
\hline 12 no a Do you intend to systematically screen older patients at your ED? & 10 & 8 & 0.73 & 0.081 & 0.703 & Revised \\
\hline 12 no $b$ Which of the following tools do you plan to use? & 11 & 8 & 0.73 & 0.081 & 0.703 & Revised \\
\hline 13 Is there a geriatric day clinic in your hospital? & 10 & 11 & 1.00 & 0.000 & 1.000 & Accepted \\
\hline 13 yes Which facilities does the geriatric day clinic have? & 10 & 10 & 0.91 & 0.005 & 0.909 & Accepted \\
\hline 13 no Do you intend to implement a geriatric clinic in your hospital? & 10 & 8 & 0.73 & 0.081 & 0.703 & Revised \\
\hline 14 Indicate which of the following programs are available in your hospital? & 8 & 11 & 1.00 & 0.000 & 1.000 & Accepted \\
\hline $\begin{array}{l}15 \text { Are there structural collaborations with external partners (nursing home, general } \\
\text { practitioners, home care organizations, case managers) to ensure coordination and continuity }\end{array}$ & 10 & 10 & 0.91 & 0.005 & 0.909 & Accepted \\
\hline
\end{tabular}




\begin{tabular}{|c|c|c|c|c|c|c|}
\hline of care after hospital discharge (i.e. transitional care programs)? & & & & & & \\
\hline $\begin{array}{l}15 \text { yes Please describe what type of transitional care programs exists and which internal and } \\
\text { external healthcare professionals are involved. }\end{array}$ & 8 & 9 & 0.82 & 0.027 & 0.813 & Accepted \\
\hline 15 no Do you intend to implement transitional care programs in your hospital? & 10 & 8 & 0.73 & 0.081 & 0.703 & Revised \\
\hline $\begin{array}{l}16 \text { Is there anything else you want to add concerning the organization and implementation of } \\
\text { geriatric care models in your hospital? }\end{array}$ & 11 & 11 & 1.00 & 0.000 & 1.000 & Accepted \\
\hline
\end{tabular}

${ }^{\mathrm{a}} \mathrm{I}-\mathrm{CVI}=$ item-level content validity index; ${ }^{\mathrm{b}} \mathrm{P}_{\mathrm{C}}=$ probability of a chance occurrence; ${ }^{\mathrm{C}}$ kappa designating agreement on relevance; ${ }^{\mathrm{d}}$ Rejected=kappa

$<0.40$; Revised=kappa 0.40-0.74; Accepted=kappa >0.74 